\title{
DESAFÍOS DE LA GEOGRAFÍA HISTÓRICA EN LA INTEGRACIÓN DE LOS ANDES Y LAS ZONAS ÁRIDAS*
}

\author{
CHALLENGES OF HISTORICAL GEOGRAPHY IN THE INTEGRATION \\ OF THE ANDES AND THE ARID ZONE
}

\author{
Pedro Cunill Grau**
}

La emoción me embarga al recibir esta gentil invitación de las autoridades del Trigésimo Tercer Congreso Nacional y Dieciocho Internacional de Geografía, organizado por el Departamento de Ciencias Históricas y Geográficas de la Facultad de Educación y Humanidades de la Universidad de Tarapacá, y la Sociedad Chilena de Ciencias Geográficas, para dictar la Conferencia Magistral en la inauguración del Congreso en esta entrañable ciudad de Arica, cara a mis recuerdos más íntimos. Lo agradezco muy singularmente, estando muy emocionado por este alto honor que se me concede después de una ausencia de 36 años de mi patria natal.

Gracias a todos ustedes, colegas de siempre, compañeros en la saga de la docencia, la investigación y la extensión geográfica, y muy particularmente a mis exalumnos Alejandro Tapia y a Mónica Meza por sus innumerables cuidados y atenciones que han hecho posible este viaje desde la Tierra de Gracia al Finibusterre Austral.

$\mathrm{Al}$ aceptar este convite a participar en el marco del gran tema Geografía de los Andes y el Desierto: Territorio e Integración, me permití sugerir el tema Desafíos de la geografía histórica en la integración de los Andes y las zonas áridas, a base de mis investigaciones durante más de cincuenta años en esta temática. Desde mis primeras clases universitarias había mantenido la ensoñación de las ventajas sociales y económicas de una futura integración latinoamericana. Mi maestro Pierre George me posibilitó expresar en un libro la realidad prospectiva de esta ilusión al invitarme en 1963 a redactar en la Colección Magellan, que él dirigía, el volumen sobre América Andina.

Para ello, además de documentarme al respecto, realicé varios viajes a los países andinos, impactándome mi primera aproximación a los paisajes desérticos chilenos desde Arica, Iquique, Antofagasta. Todo ello culminó en una larga estadía en Venezuela durante dos años, donde fui invitado a solicitud de mi otro gran maestro chileno Humberto Fuenzalida, por la Escuela de Geografía de la Universidad Central de Venezuela, aproximándome así a los paisajes de tropicalidad. Allí culminé esta obra que apareció en 1966 bajo el título de L'Amerique Andine, Presses Universitaires de France, Paris.

Al escribir su primera edición insistí en presentar, de una manera integral sin fronteras políticas, los problemas geográficos comunes para el conjunto de estas naciones andinas, rechazando el tratamiento clásico de una descripción de país por país. Para ello tuvimos que superar incomprensiones de quienes se referían a este planteamiento del conjunto multinacional como "una utopía" o un "absurdo geográfico".

Los años fueron pasando y, en el lapso en que aparecían en 1968 en portugués, en la serie brasileña de Terras e Povos de São Paulo; en español en la Editorial Ariel de Barcelona en la Colección Elcamo en 1978 y 1981; y en 1980 la segunda edición francesa, se había iniciado un proceso de reconocimiento y consolidación de esta realidad geográfica que se extiende vertebrada por la cordillera de los Andes desde el Caribe hasta el Polo Sur. Surgió el Acuerdo de Cartagena y otras instituciones integracionistas que cubren este ámbito territorial, culminando con los avatares de la Comunidad Andina de Naciones. Todo ello ha tomado nuevos horizontes con la articulación y mayor significación de las naciones andinas en diversos procesos de integración, en especial al

* Discurso inaugural pronunciado en la ciudad de Arica (Chile) el año 2012 con motivo del XXXIII Congreso Nacional de Geografía y el XVIII Congreso Internacional de Geografía, organizado por la Sociedad Chilena de Ciencias Geográficas y el Departamento de Ciencias Históricas y Geográficas de la Universidad de Tarapacá.

** Universidad Central de Venezuela. Caracas, Venezuela. Correo electrónico: pedrocunill@ hotmail.com 
Mercado Común del Sur (Mercosur); a la unión de Naciones Suramericanas (Unasur) y a la Alternativa Bolivariana para las Américas (Alba).

Además vuelco en esta conferencia algunas de mis contribuciones expresadas en La Geohistoria, Fondo de Cultura de México, El Colegio de México, en la obra colectiva Para una Historia de América. Las estructuras, 1999 y en la Geohistoria de la sensibilidad de Venezuela, ediciones Fundación Empresas Polar, Caracas, 2011, aparte de otras contribuciones y aportes personales. Son materiales a debatir con los asistentes a este evento.

\section{Los desafíos geohistóricos y sus especifidades en la geografía cultural}

Este discurso es una modesta contribución a la geografía de la percepción de diversos factores en la integración de los Andes y sus zonas áridas. Estimamos que ello nos posibilita incursionar en la recuperación de una herencia geohistórica común, en raíces sólidas que reverdecen hoy, legadas en su conocimiento por diversos aportes de geógrafos e historiadores clásicos, cronistas acuciosos, misioneros y confesores, viajeros avizores y por otros múltiples testimonios documentales, incluso de literatos, novelistas, poetas y músicos, que habían sido soterrados por la indiferencia de los cultores de la vana geografía descriptiva y meramente enumerativa, como también por una elemental geografía cuantitativa neopositivista.

Pretendemos enfocar nuevas ópticas en nuestra común geografía cultural, viendo en las milenarias y seculares estructuras territoriales concretas y en la organización social del espacio de América Andina, la puesta en forma de un imaginario poblado de símbolos, de visiones, de sueños, de sonidos y silencios.

Aquí caerán los mitos de espacios vacíos y fronteras, como también los de las fronteras naturales infranqueables que impedían todo tipo de integración. Luego insistiéremos en motivar a nuestros investigadores en el aborde en sus futuros trabajos a temáticas específicas de la geografía de la sensibilidad. Presentaremos una decena de temas al respecto, entre ellos, vivificar las rutas geohistóricas; sentir olores y aromas; el mestizaje de sabores; sales y dulzuras; las rutas de drogas, tabacos, hierbas y venenos; los espacios de distensión y del ocio; sentimientos del ver y vivir en sociedades andinas; $\mathrm{y}$ al rescate del buen vivir.
La cambiante geografía de la percepción es la clave para entender la geografía histórica del comportamiento humano en la conformación y utilización de los paisajes de América Andina. No existe un paisaje inmutable, que objetivamente proporcione su biodiversidad y sus recursos naturales. Todo paisaje es interpretado y percibido variablemente por las geografías personales, inmersas en sus respectivas expresiones vívidas, históricas y sociales. Es decir, según nuestro criterio, la visión del paisaje geográfico andino y desértico es personal, social, mezclando la realidad con la fantasía, con los sueños, con los temores, con las esperanzas, que tiene todo ser humano.

En la geografía humanista se intentan aprehender los significados, los valores, los objetivos, los propósitos, las intenciones voluntarias e intervenciones espontáneas o forzadas, que expresan creativa o destructivamente diversas acciones humanas.

Por lo tanto, en nuestro caso de América Andina nos resulta fundamental el aborde conceptual de sus paisajes culturales mediante la percepción geohistórica. A este respecto, debemos evitar interpretaciones anacrónicas, antihistóricas, que intentan retrotraer a los siglos XV, XVI, XVII, XVIII, XIX y comienzos del siglo XX, percepciones del hoy, manteniendo aversión contra hábitos de aseo, ornato, alimentación, vestimenta, medicina y otros. Incluso incomprensión y prejuicios a diversas manifestaciones de la sensibilidad regional. Por ello, nuestras palabras comprenden una visión territorial de la sensibilidad en Andes y zonas desérticas en una óptica humanística de la geohistoria de la percepción que se marca desde el tardío siglo XV al temprano siglo XX.

\section{Espacios vacíos y fronteras: una inexactitud geohistórica}

En nuestras obras hemos intentado la comprensión de espacios fronterizos de América Andina no como espacios vacíos separados por barreras naturales, sino como sitios de encuentro ancestral, de honda raigambre indígena y legado secular de diversos tipos de colonización de pueblos originarios y criollos.

Esta concepción de los espacios fronterizos como hábitat ha sido recogida, entre otros especialistas, por Juan Álvarez Cienfuegos, quien reacciona contra el término de fronteras naturales: "entonces, se considera que cadenas montañosas, ríos caudalosos 
e inhóspitos, mares, son elementos de separación, se presentan como barreras que impiden el paso de un lugar a otro o de tal manera que hacen imposible la comunicación, el intercambio y el tráfico, condenando a los espacios que caen a cada lado a permanecer ajenos el uno del otro". Explicita que estos límites en apariencia infranqueables tienen sus porosidades: "Qué duda cabe de que las montañas, los ríos o los mares dividen los espacios, pero también en ocasiones son precisamente elementos de unión; en las altas montañas del Pirineo se juntan los pastores de las dos vertientes con sus rebaños en los calurosos meses de verano; entre la orilla este y oeste del Río de la Plata hay un tráfago incesante" (Cienfuegos, 2005).

En este contexto no tienen vigencia los espacios fronterizos vacíos en América Andina, sino espacios fronterizos de hábitat humano, siendo lo que se observa, por ejemplo, entre los pueblos originarios de similares etnias, lo que se expresa en que espacios que eran conceptualizados como vacíos, bien acotados en los mapas oficiales de diversas repúblicas americanas, son en verdad, por la realidad geohistórica, espacios de encuentro étnico en múltiples sitios de la vertebración de los Andes, zonas desérticas, costeñas y en sus extensiones de la América profunda orinoquense y amazónica.

La percepción dominante en diversos tratadistas del poblamiento fronterizo iberoamericano colonial y republicano era de considerar como desierto, despoblado, espacio vacío o territorio inhabilitado, a los espacios geográficos que habían sido poblados milenariamente por etnias indígenas. Para blancos europeos y mestizos criollos esta presencia indígena aboriginaria no tenía importancia, debido a que no translucía en su hábitat permanente, seminómade o nómade, las huellas de la culturización occidental iberoamericana.

Prejuiciosamente eran conceptualizados como espacios de salvajes, tierras incultas sin roturar, espacios fronterizos a conquistar, en otras palabras, era la conquista del desierto. Expresión discutible que quedó entre otros casos con la misma apelación en la literatura clásica geohistórica argentina que se refiere a este proceso como a la lucha contra el indígena, desde el aspecto puramente militar, de avances y retrocesos de la frontera en líneas defensivas $\mathrm{y}$ de las acciones libradas contra los moradores del pretendido desierto (Allende, 1958; Randle, 1966; Carzolio, 1971). En Argentina, junto al avance en forma de abanico y con marcada tendencia hacia las tierras pampeanas, es también innegable la gravitación de la frontera contra el indígena en la tardía integración de la Patagonia en la extensión oriental de los Andes y el Chaco como una tierra impenetrable y salvaje: "se perpetuó en el tiempo alimentada por los informes de cronistas viajeros expedicionarios y militares que se explayaron en sus relatos respecto de las dificultades que implicaba el arraigo en el desierto verde, denominación usada por entonces para distinguir a estas comarcas de los áridos territorios del sur, sometidos poco antes a un similar plan de ocupación" (Mari, 2003). En 1910, aún en plena campaña contra los pueblos originarios aborígenes, la viajera sueca Ida Backman aseguraba que "la palabra Chaco, desierto aún para los argentinos, es sinónimo de la peor clase de salvajismo" (Mari, 2003). Lo cierto es que el territorio fronterizo chaqueño no era un espacio despoblado, un territorio vacío, sino una superficie geográfica densamente habitada por siglos por ancestrales pueblos originarios, a los cuales el blanco y el criollo tuvieron que desplazar, junto con vencer, a una enmarañada vegetación y un clima severo.

Singular, aunque con ciertas similitudes con la "conquista del desierto" de la pampa argentina, fue en América Andina la fase final de la ocupación fronteriza por Chile de los territorios mapuches conocida como la "pacificación e incorporación de la Araucanía", que iniciada en 1859 culminó en 1883, con avances y retrocesos del ejército, de fundación y destrucción de fuertes, de alzamientos indígenas. Fue un tema controversial, porque mientras en 1845 el científico polaco Ignacio Domeyko, residenciado en Chile, propiciaba que la incorporación debería efectuarse en forma pacífica, por misiones católicas, Andrés Bello pensaba que los hechos habían probado reiteradamente el fracaso de las misiones, no habiendo otra forma de someter a los araucanos sino con las armas, aunque estimaba que debía empleárselas con reservas, en ningún caso en una ofensiva sangrienta (Villalobos, 1995).

En los hechos esta pacificación, con los procesos de invasión de las tierras comunes mapuches, aparentemente vacías se realizó en varias campañas del ejército. En obras diversas se proporcionan voces disidentes acerca de las consecuencias de esta incorporación fronteriza, contraponiendo la visión optimista de europeos y criollos que consideraban un gran triunfo haber posibilitado roturar bosques y praderas australes cuasivírgenes al entregarse a colonizadores para una gran explotación triguera: 
"Para los mapuches, la realidad a partir de la $p a$ cificación fue menos risueña. Este gran espacio comprendido entre el Malleco y el Toltén se incorporó a la República de Chile formando un territorio de colonización, más de dos millones de hectáreas fueron otorgadas o rematadas, creándose grandes haciendas y recurriendo de preferencia a colonos extranjeros más que a nacionales" (Casanueva, 1998; Cunill, 1972). Desde entonces, hace 130 años, la tenencia de la tierra se transformó en el problema básico en la vida del pueblo mapuche. Estas etnias fueron circunscritas a terrenos denominados reducciones, en territorios exiguos de suelos pobres y áridos, donde solo es posible una baja calidad de vida, tendiendo a emigrar a centros urbanos del sur y centro de Chile. Subsiste hasta la fecha una grave situación económica, cultural y social del pueblo mapuche (Saavedra, 1971). Tema crucial que tendría que ser objeto de innovadoras investigaciones geohistóricas y geoprospectivas.

\section{El mito de las fronteras naturales infranqueables}

Hasta comienzos del siglo pasado en los extensos lindes de América Andina dominaban espacios naturales sin gran intervención permanente de ocupación antrópica, con escasas densidades de poblamiento aborigen. Este virtual despoblamiento humano en inmensas superficies de lindes y fronteras planteó de partida un desafío diferente a otras zonas limítrofes sujetas a largas y sostenidas interacciones geográficas humanas, como las que se registran en Europa y Asia. Sin embargo, esta condición de desiertos-fronteras, como las ha descrito el reputado geohistoriador Roger Dion (Dion, 1947), no permite mantener la posición de algunos tratadistas que en el pasado e incluso en el presente han enfatizado en la inviolabilidad e impenetrabilidad de fronteras nacionales, siguiendo el epíteto expresivo de Julio César del nativus murus o muro natural, en referencia al linde boscoso entre los pueblos germánicos suevos y queruscos. Como lo ha sintetizado Jaime Vicens Vives está absolutamente superado en los geopolíticos más avanzados el concepto de frontera natural, aparentemente defendible por la inaccesibilidad de vegetación selvática, desiertos ríspidos, relieves o barreras fluviales (Vicens Vives, 1958). Incluso, como lo expuso el gran geógrafo Jules Brache, las montañas tienden más bien a aglutinar la cultura de pueblos fronterizos en sus dos vertientes y servir de santuario o refugio a los perseguidos (Blache, 1942).

En las tierras andinas eran sumamente dificultosos los movimientos de múltiples tipos de peregrinaciones en el Incanato hacia espacios sacros inaccesibles de significación sobrenatural, como las de multitudes quejumbrosas que iban de cerro en cerro implorando agua de lluvia, o las procesiones multitudinarias a cumbres, lagunas y otros accidentes topográficos para impedir granizos, heladas, rayos o epidemias, como lo describió Felipe Guaman Poma de Ayala en los últimos años del siglo XVI en su Nueva Corónica y Buen Gobierno. Auténticas hazañas de escalamiento tuvieron que efectuar dignatarios y pobladores para trepar por grandes pendientes hasta alcanzar las altas cumbres andinas, donde emplazaban sus santuarios de sacrificio al culto solar, como los que se encontraron en 1954 en la cumbre del cerro El Plomo a $5.430 \mathrm{~m}$ de altitud, o en 1995 en el monte Ampato a $6.309 \mathrm{~m}$ en el noreste de Arequipa. Testimonios de paisajes de integración sacra solar se han encontrado también, entre otros sitios, en las cumbres de los cerros Tórtola y Doña Ana, que dominan el valle del Elqui, del Licancabur, del Llullayllaco y otras en los espacios fronterizos de las actuales naciones del Perú, Bolivia, Chile y el nordeste argentino. A su vez, los chibchas, que ocupaban las mesetas centroorientales de las tierras altas de Colombia, organizaban peregrinaciones de ofrendas a los lejanos e infranqueables sitios sagrados de cavernas, montañas y lagos.

Asimismo se ha demostrado por diversos autores la fragilidad absoluta de la teoría de las fronteras fluviales, donde el río se comporta como una supuesta frontera natural, observándose en cambio una tendencia unificadora de los núcleos de poblamiento afincados en una cuenca fluvial binacional. Vicens Vives es tajante al respecto: "jamás el talweg de un río ha separado pueblos, culturas, razas, religiones o economías. El río frontera es un sueño alimentado por una diplomacia fosilizada" (Vicens Vives, 1958).

En el caso sudamericano tenemos el caso relevante del río Orinoco que ha conformado un eje natural de comunicaciones fluviales, no conformándose como una frontera natural impenetrable e infranqueable. Desde la prehistoria hasta la época contemporánea su cuenca hidrográfica ha sido un lugar de encuentro cultural y económico. Durante milenios se han superado los obstáculos de sus raudales de Atures, Maipures y otros saltos interiores, como asimismo los períodos de excesivas 
crecidas y de extremadas secas. El Orinoco ha sido, con todo su sistema fluvial, una arteria viva, cuya funcionalidad se remonta e períodos prehispánicos. Solo en períodos históricos coloniales y republicanos fue conceptualizado como una frontera natural que debía ser fortificada para que fuera infranqueable.

Por el contrario, el sistema del Orinoco ha cumplido su rol de intercambiador fronterizo. Incluso se ha planteado la audaz hipótesis de la rapidez de las interrelaciones prehispánicas y posthispánicas que establecieron entre sí, con enorme capacidad de movilización, los indígenas que formaron parte del complejo cultural Caribe, Tupí y Guaraní, en los espacios geográficos drenados por los ríos Orinoco, Amazonas, Panamá-Paraguay y los sistemas litorales e insulares caribeños y atlánticos (Parés, 1995). El mito de una frontera natural fluvial infranqueable, muy divulgado por numerosos tratadistas que han insistido en lo impenetrable del interior sudamericano, ha sido develado por reputados arqueólogos que han comprobado el uso intensivo de la red fluvial del Orinoco y del Amazonas, con el diseño cultural de una importante vía comercial indígena, que iba desde el Orinoco por el Guaviare y los afluentes del Japurá, hasta las tierras altas del Putumayo y el Napo; a su vez, diversas etnias indígenas utilizaban la conexión por el Casiquiare, río Negro y del río Blanco, que unía los territorios guayaneses con la macrocuenca del Amazonas.

Una vez más, en los hechos prehispánicos americanos se comprueba la fragilidad de la teoría de las fronteras fluviales, demostrándose en cambio como importancia de las márgenes del Orinoco para fijar núcleos de población indígena, siendo este elemento acuático lo que permitía y propiciaba la diseminación de los grupos humanos y de las influencias culturales dentro de la misma cuenca orinoquense y su irradiación hacia otras cuencas hidrográficas (Sanoja, 1992). En efecto, en trabajos anteriores hemos expuesto que ante la ausencia de caminos terrestres y la gran dificultad de apertura de trochas en la densa selva siempre húmeda, era fundamental el significado de las rutas acuáticas orinoquenses para el tráfico cotidiano y los desplazamientos a enormes distancias (Cunill, 1998).

Son las sociedades humanas las que conforman sus lindes en su devenir histórico, con avances y contradicciones, superando los marcos de las aparentes fronteras naturales. Es el caso de parajes colomboperuanos de la región amazónica emplazada entre los ríos Caquetá y Putumayo, que eran descritos en el caso colombiano de los pueblos aborígenes Andaquíes en 1857 como pueblos felices en sus modos de vida ${ }^{1}$. Pocos años más tarde, en los inicios de la explotación del caucho, que se remontaba hacia los finales de la década de 1870 en estos parajes, manteniéndose con gran auge hasta aproximadamente 1912, llegando a representar en 1910 el 30\% del total de las exportaciones peruanas, posibilitó un vigoroso sistema de explotación, no respetándose los hitos fronterizos, dilapidándose recursos de flora y expoliándose a los pueblos originarios amazónicos y a los serranos andinos enganchados que se llevaban a trabajar en la Amazonia.

Los recolectores del caucho silvestre tenían que vivir en condiciones paupérrimas en total aislamiento geográfico. Los grandes empresarios, como el peruano Julio César Arana, quien creó un imperio personal con capitales británicos con la Compañía Limitada Amazónica Peruana, organizaban correrías, que eran expediciones de reconocimiento y recolección de la goma, donde los caucheros entraban en la selva liquidando poblaciones de los pueblos originarios y secuestraban a sus habitantes obligándoles a trabajar por medio del castigo, las torturas, la extorsión y el secuestro. Aquí no se respetaban fronteras naturales, ya que estos pasajes estaban ubicados en una región en disputa entre Perú y Colombia (Contreras y Cueto, 2007). Estas correrías sirvieron de inspiración a Mario Vargas Llosa para su novela El sueño del celta, 2010, donde narra la peripecia vital del irlandés Roger David Casement.

La zona del Caquetá-Putumayo, que ya no era en la primera década del siglo pasado una tierra incógnita periférica de América Andina, se hallaba prácticamente desamparada de cualquier control estatal nacional fronterizo, siendo el único gobierno de facto la compañía peruano-británica manipulada por Julio César Arana. Estableció numerosos campamentos caucheros, de estos algunos sobreviven en la toponimia de la antigua Comisaría del Amazonas colombiano, entre ellos el denominado Arica en las márgenes del río Putumayo en las cercanías donde confluye el río Igara Parana. Tema cautivante geohistórico que debería ser investigado por geógrafos de esta región, al existir allí también el sitio de Tarapacá.

La riqueza del caucho llevó incluso a efectuar correrías en territorios fuera de discusión fronteriza en la república de Colombia, al norte del río Caqueta. Se denotaron movimientos de segregación de la república de Perú en rebeliones que debieron ser sofocadas con envío de tropas, que tuvieron 
una dificultosa travesía por los océanos Pacífico y Atlántico llegando al escenario geográfico del conflicto con más de un año de retraso. En 1921 apareció otro intento separatista con la instalación de un gobierno provisional en Iquitos (Contreras y Cueto, 2007).

Estos procesos de ocupaciones de facto en territorios aparentemente inaccesibles se marcaron también, entre otros lugares, en las discrepancias fronterizas entre Bolivia y Brasil, suscitadas a partir de 1899 con motivo del auge de la explotación del caucho en la región amazónica, los que desembocaron en la Guerra del Acre, entre 1902 y 1903. Fue un desastre territorial cuyas huellas calaron profundamente en los procesos históricos bolivianos en las siguientes décadas. El fin de esta Guerra del Acre se marcó con la firma del Tratado de Petrópolis, cediendo Bolivia al Brasil 191.000 $\mathrm{km}^{2}$ (Arze, 1999).

El mismo historiador René Arze Aguirre ha expuesto que el desafío del avance de las tierras altas bolivianas a los espacios de la frontera sudeste del país del Chaco boreal fue un intento crucial en la tarea de impedir mayores mutilaciones territoriales, como las evidenciadas en la Guerra del Pacífico y en la Guerra del Acre, y de conseguir un acceso marítimo al Atlántico por el Paraguay. En junio de 1932, después de una década de construcción de fortines y envíos de destacamentos militares en esta región sumamente inhóspita, Bolivia y Paraguay iniciaron una violenta disputa por estos territorios, que solo finalizó en julio de 1935 con un pacto de tregua. En esta Guerra del Chaco los soldados bolivianos que fueron llevados a los impenetrables y ardientes tuscales de arbustos espinosos, insalubres y faltos de recursos alimentarios, percibidos como el infierno verde, provenían mayoritariamente de etnias aymaras y quechuas de las altas mesetas y serranías andinas. Esta Guerra del Chaco condujo a la muerte de 60.000 soldados, originarios de los Andes. El corolario se marcó en el Tratado de Paz, Amistad y Límites, de julio de 1938, por el que los límites de Bolivia quedaron emplazados lejos del río Paraguay.

En el extremo Austral de América Andina, en toda la falda occidental de los Andes desde el archipiélago de Chiloé hasta el cabo de Hornos, procesos de colonización ganadera, caza expoliadora de las focas y nutrias, explotaciones no renovables del ciprés y del alerce, errada política de concentración misional y otros factores socioeconómicos, condujeron a la desaparición de pueblos aborígenes chonos, alacalufes, yaganes, que se habían estimado a salvo por su condición de pueblos nómadas en archipiélagos virtualmente inaccesibles, sometidos a severas condiciones ambientales, lluvias, vientos, tempestades, con omnipresencia de bosques impenetrables, turberas gelatinosas, lodazales y campos de hielo. El proceso ha sido magistralmente expuesto por Joseph Emperaire en su obra Los nómadas del mar, siendo patético su capítulo sobre los ritos de la muerte en los alcalufes (Emperaire, 2002). Igualmente no existieron fronteras naturales infranqueables en la vertiente oriental austral andina, siendo depredadoras las acciones de ganaderos, colonizadores y misioneros, en sus contactos que condujeron a la desaparición de tehuelches, los antiguos patagones, que habitaban la meseta patagónica austral, que se extiende entre el estrecho de Magallanes, la costa atlántica y la precordillera andina, y los onas de Tierra del Fuego.

\section{El rigor de las travesías por los desiertos de América Andina}

Las sociedades indígenas en los Andes Centrales debieron enfrentar inhóspitos ambientes desérticos, rechazándose la implantación permanente y densa en los sitios más secos de los desiertos costeros de Sechura y Atacama, que actuaron como barreras poco permeables a la integración y penetración humana en sus confines Norte y Sur. En el extremo septentrional, el desierto de Sechura contribuyó a aislar Piura y Tumbes del resto de la hiperárida costa peruana. En el extremo meridional, del aislamiento relativo y comportamiento insular de Chile Central.

Las pronunciadas constricciones físicas de la sequedad absoluta y escasez de biodiversidad de flora y fauna e imposibilidad de agricultura basada en la pluviosidad local condicionaron a las comunidades más primitivas de pescadores y recolectores al desenvolvimiento de mecanismos de sobrevivencia, como diversas artes de pesca y marisqueo, caza de pinnípedos, aves y animales, austeridad en los alimentos y en el consumo de agua potable, expresándose en poblaciones muy pequeñas, que subsistían dificultosamente en caletas desdeñadas por comunidades más avanzadas, perdurando algunas, como las de los changos, hasta mediados del siglo XIX.

En los límites septentrionales del desierto de Atacama solo se vieron superadas las condiciones 
sumamente secas en escasos valles transversales que se despliegan entre Arequipa y el río Camarones, conformando, como ustedes bien lo conocen, la cultura Arica, con pueblos agroalfareros que aprovechaban con gran sabiduría los escasos recursos fluviales.

En cambio, en la extensa zona desértica central del desierto de Atacama dominaba el despoblamiento absoluto distinguiéndose apenas los pequeños oasis atacameños y los contornos del río Loa, con aldeas dispersas de alta densidad poblacional en los complejos Pica, Lasana y San Pedro de Atacama, con grandes intercambios de productos entre el océano Pacífico y la alta cordillera andina. En estos puntos el desierto parecía haber sido vencido definitivamente con las expresiones paisajísticas del notable desarrollo urbano en las apretadas ciudades fortificadas o pucaras de Turi, Lasana, Quitor, Cupo y otras, y en los núcleos más desparramados o "pueblos viejos", como Zapar, en el camino entre San Pedro de Atacama y Toconao, o posteriormente en los tambos y tambillos, sitios donde los viajeros del camino de los Incas conseguían posada y provisiones para ellos y sus tropillas de llamas, como el de Catarpe (Le Paige, 1957; Mostny, 1974). Todos ellos fueron invadidos por el desierto, a diversa intensidad, en tiempos históricos.

En la mapoteca de la Biblioteca Nacional hemos podido consultar en sus originales dos preciosas fuentes cartográficas de gran interés para el estudio de los establecimientos de los paisajes permanentes y efímeros de los oasis de los desiertos nortinos. Aunque estas piezas fueron mencionadas por Ernesto Greve en 1938 (Greve, 1938). Permanecieron virtualmente perdidas hasta 1972 y se hallaban inéditas a pesar de su extraordinario valor geográfico-histórico. La primera tiene el siguiente título: "Plano que manifiesta la quebrada de Tarapacá en el Thenientazgo o Partido de este nombre, Jurisdicción del Corregimiento de la ciudad de San Marcos de Arica, con las tierras de los indios tributarios, y el proyecto que se discurre muy útil para dar corriente a las lagunas de Lisima, y el proveer de agua esta quebrada, y el valle de Iluga. Levantado de orden del Excelentísimo señor don Manuel de Amat y Junient, por don Antonio O'Brien, en el año de 1765 ". Esta pieza documental mide alrededor de 1,80 metros de largo y poco más de un metro de ancho, proporcionándonos una extraordinaria riqueza de topónimos culturales, aun prehispánicos como las menciones a adoratorios y cementerios de gentiles, destacando las precisas notas cartográficas sobre la estructura de los establecimientos de indígenas encomendados y aprovechamiento del suelo. La otra fuente cartográfica se señala con el siguiente título "Plano que manifiesta el Valle o Pampa de Iluga, en el Thenientazgo de Tarapacá, Jurisdicción del Corregimiento de la ciudad de San Marcos de Arica, con las quebradas más notables que desembocan en él. El agua que por dichas quebradas baja en tiempo de lluvias en la Cordillera. Los bosques y tierras que se sembraban en tiempos pasados cuando llovía en dicho valle, los caminos que lo cruzan y los sitios que tienen nombre. Levantado de orden del Excelentísimo señor don Manuel de Amat, por don Antonio O'Brien, el año de 1765". Es una fuente cartográfica indispensable para la investigación de los paisajes agrarios del siglo XVIII en las quebradas de Tarapacá, Aroma y próximas, con el emplazamiento de chacras intermitentes, puquios o fuentes en pozos o estanques de estrechas dimensiones, localidades y la distribución de senderos y caminos. Ambos mapas nos dan luces sobre el gran tema del regadío y de la utilización del agua en los paisajes agrarios del desierto (Cunill, 1972).

Igualmente se ha evidenciado una gran regresión de los paisajes culturales en los desiertos de altura en la puna de la zona oriental de Bolivia de los pueblos caranga, que se hallaban ubicados en los tiempos de la conquista entre el río Desaguadero y el salar de Coipasa, y los pueblos lípez en Potosí, como también en la puna Argentina en las construcciones de los grupos Yavi y Casabino, como en el espectacular pucara de Rinconada.

En las travesías del desierto de Atacama fue fundamental el apoyo el Qhapaq Nan, y la mayor parte de sus comodidades en los establecimientos de tambos y la agricultura de los oasis fueron aprovechadas por los conquistadores en los tiempos coloniales, por lo que en aportes cartográficos tardíos, como el Mapa Geográfico de América Meridional, dispuesto y grabado por Juan de la Cruz Cano y Olmedilla en 1775, se podía seguir todavía su trazado y establecimientos de posada.

Sin embargo, las dificultades del desierto fueron determinantes para los conquistadores españoles, aprovechándose solo de paisajes de escalada en el trayecto hacia Chile Central y Alto Perú. El tráfico era condicionado por escasas aguadas, que con su magra provisión de agua y forraje podían asegurar dificultosamente el paso por el desierto, siempre que la travesía se hiciera de vez en cuando y en pequeños 
grupos, para dar así tiempo a que se recuperaran los recursos acuíferos, siendo empleada esta logística tanto en el regreso de la expedición de Diego de Almagro como en la de Pedro de Valdivia. Tema que ha sido bien investigado por diversos antropólogos e historiadores, que debería ser continuado por las diferentes sagas en su utilización en los siglos coloniales y republicanos. Una incógnita a resolver se plantea en el trazado de caminos actualmente desaparecidos, desde tambos sin agua a lejanos sitios cuando probablemente existiría algún recurso hídrico.

Estos paisajes deshumanizados por la aridez se definían como el Despoblado, manteniéndose apenas el poblamiento en los oasis más conspicuos ariqueños, iquiqueños, de San Lorenzo de Tarapacá y de San Pedro de Atacama, siendo vencidos los obstáculos del desierto solo por la persistencia de recuas de mulas y llamas por los caminos del Despoblado que unían mediante este desierto absoluto las comarcas de Perú, Charcas y Chile.

\section{El desafío de vivificar rutas geohistóricas prehispánicas y coloniales}

Estimamos que hay que incorporar a historiadores, geógrafos, antropólogos y otros científicos a efectuar nuevas investigaciones y proyectos aplicados en América Andina sobre las rutas para el diálogo intercultural, los itinerarios culturales y las rutas turísticas culturales. Son temas que se están desarrollando mayoritariamente gracias al impulso realizado por organismos internacionales de cooperación, como la UNESCO, MERCOSUR, Agencia Española de Cooperación Internacional (Programa ACERCA) con el apoyo del sector público, privado y la sociedad civil.

A este respecto fue muy útil el Simposio sobre Rutas e Itinerarios Culturales Iberoamericanos que se realizó en el marco del 53 Congreso Internacional de Americanistas en México en julio del 2009, donde se presentó el estado de la cuestión de las investigaciones y proyectos a escala trasnacional, analizándose las estrategias de conservación y valoración, los modelos de gestión, la participación de los agentes, los indicadores de desarrollo y la gestión turística cultural.

El principal desafío en América Andina consiste en revivificar el legado cultural del Qhapaq Ñan, que es en lengua quechua, el camino del señor, camino principal de una extensa red de comunicaciones que se había estructurado a lo largo de los muchos siglos de la civilización andina y que los Incas del Cuzco habían articulado en el siglo XV.

Cinco mil km fueron cubiertos por el Qhapaq Ñan, con una red que superaba los $30.000 \mathrm{~km}$ de caminos habilitados. Por el norte llegaba cerca del cauce del río Guáytara en el sur de la actual Colombia, pasando por los Pastos, más allá de Quito e Ibarra, mientras que por el sur culminaba en los lindes del río Maule en el centro-sur de Chile, y la tierra de los huarpes en Argentina. Estos caminos peatonales y de llamas impresionaron en 1532 a los españoles que los encontraron en pleno funcionamiento, ya que en Europa no se tenía algo parecido desde los tiempos del Imperio Romano.

El rescate de su legado cultural se ha promovido desde 2002 por el Instituto Nacional de Cultura del Perú (INCP), teniendo un indudable interés geohistóricos su Proyecto Chapag Ñan, que consideramos de dimensión universal (INCP, 2004). Este monumental régimen caminero tenía trazos bien delimitados, con señalizaciones de las rutas, con maquetas o rocas labradas que mapeaban el relieve, con establecimiento de tambos vinculados al alojamiento de los transeúntes y al almacenaje; de kanchas, recintos rectangulares amurallados que eran utilizados como alojamientos a los caminantes y también para viviendas permanentes; las kallankas, galpones de tamaño considerable destinados al alojamiento, que aparecen en los tambos de los tramos de Cusco a Quito; las colcas o qollqas, silos de piedra de diversas formas que son almacenes de alimentos y utensilios. La emoción nos embarga cuando todavía vemos en estos parajes las apachetas o acumulación de piedras depositadas por los viajeros: "que les confieren la acepción de lugares sagrados para acortar distancias, aliviar el cansancio y evitar los contratiempos en el viaje. Se localizan en los bordes del camino en los espacios de transición entre las diferentes unidades del relieve o en el punto donde se visualizan los hitos geográficos" (INCP, 2004).

Así, los séquitos de dignatarios, los ejércitos, los viajeros y recaudadores, acompañados por recuas de camélidos, transitaban cómodamente por senderos firmes y bien trazados, utilizando en diversos tramos escalinatas, rampas, puentes de varios tipos, como de piedra o rumichaka, de madera, colgantes, oroyas o huaros, e incluso flotantes de totora como los que se distinguían en el lago Titicaca. Estaban protegidos por muros de 
contención, pircas de refuerzo, canales de drenaje, terraplenes y calzadas elevadas.

De esta manera el Qhapag Ñan se expresó en el factor comunicacional de mayor importancia en la integración de los plurales paisajes andinos. Esta compleja red, conformada por el camino principal y los caminos laterales, posibilitaba trasladarse peatonalmente de un lado a otro en el Tawantinsuyo. Los poblados de la sierra andina recibían con prontitud los productos del mar, incluso las conchas ceremoniales del ostión o mullu y del caracol pututu. Asimismo, llegaban a los valles y oasis costeros las producciones alimentarias serranas y los cueros, las maderas finas, las hierbas y las plumas de las selvas del piedemonte andino oriental y Amazonia. Es tarea de vuestra generación rescatar la magnificencia del Camino Principal Andino desde el sur de Colombia al río Maule en Chile.

A otra escala y en otros tiempos históricos nos corresponde rescatar para el imaginario geohistórico el aprovechamiento turístico y cultural de otras vías de circulación terrestre en su incidencia en los procesos de integración interna y externa colonial y decimonónica. Ustedes podrían realizar un libro colectivo, a la manera del que efectuó Ramón María Serrera sobre Tráfico terrestre y red vial en las Indias Españolas, Ministerio del Interior de España, 1992, una gran obra sobre este tema en toda América Andina, en la que Arica tuvo un importante papel. Más tarde, en el caso de los ferrocarriles, entre los cuales ameritan estudios en profundidad, serían cautivadores ensayos sobre el ferrocarril de Arica a Tacna a partir de 1860, el de Oruro a Antofagasta que ya funcionaba en 1900 y el que une Arica y La Paz desde 1913.

\section{La integración geohistórica prehispánica por la utilización de recursos naturales andinos}

En nuestras investigaciones deberemos dar especial significación a los procesos espontáneos de integración prehispánica por la milenaria utilización de recursos naturales andinos y de sus zonas periféricas, porque ha sido sumamente cambiante la percepción geohistórica de las comunidades de pueblos originarios del valor de los recursos naturales, en cuanto al aprovechamiento de los paisajes silvestres y culturales.

Durante milenios en la presencia humana de múltiples etnias no existió una invariable consideración en cuanto a la estima alimentaria y utilitaria de los recursos andinos naturales autóctonos. La extracción de diferentes minerales y piedras, las modalidades de cacería, la recolección y acopio de recursos específicos, daba lugar a procesos de integración espontánea en los variados espacios andinos y costeños. A la vez, algunos de estos recursos fueron codiciados solo en lapsos más o menos extensos por diversas poblaciones en espacios específicos, correspondiendo a la cambiante relatividad perceptiva de su valor y aprovechamiento. Estas variaciones perceptivas explican, junto a otros factores tecnológicos, ambientales y socioeconómicos, la contracción que se sucedió en múltiples paisajes.

Por ejemplo, en los Andes centrales peruanos el exceso de caza del hiparión o caballo americano y los cérvidos grandes desencadenó pronto su extinción, por lo que desde los años 7.000 a 6.000 a.C. la caza mayor en estos parajes se especializó en camélidos, siendo percibidos en nuevos espacios de integración de otra manera para su ulterior domesticación: "Dicha especialización se debió posiblemente en parte a que los cambios climáticos favorecieron el desarrollo de las especies de camélidos, especialmente vicuñas y guanacos, pero también sin duda a un mayor conocimiento de estos animales, lo que condujo a la larga a su domesticación, que también fue uno de los fundamentos más importantes de la economía andina de las sociedades posteriores" (Bate, 1983). A nuestro parecer uno de los factores más importantes para la integración geohistórica andina fue la utilización de la llama y de otros camélidos.

Los tiempos de cambio de poder y de crisis socioeconómica se suelen proyectar en la prehistoria y primeras décadas de la conquista española de América Andina en desprestigio de los conceptos sociales positivos de utilidad y valor estético de ciertos recursos naturales, anteriormente empleados por los vencidos o los empobrecidos, ambicionados por su interés emblemático, como adminículos suntuarios de prestigio, artículos ornamentales y ofrendas ceremoniales a los antiguos dioses.

En momentos claves de la prehistoria e historia andina discrepancias radicales en la percepción geográfica incentivaron alejamientos de territorios, con éxodos poblacionales y abandonos de espacios de integración al desvalorizarse sus producciones de base, las que ya no tenían interés para los vencedores. Estos, en contrapartida, implantan y movilizan otros paisajes productivos y de recorrido para satisfacer la 
provisión de nuevos recursos naturales requeridos por la sociedad triunfante y dominadora.

Fue el caso del Tawantinsuyo frente al Imperio Español, cuando además de perjudicar a recolectores, cazadores y mineros ancestrales, cambios perceptivos acarrearon en pocas décadas las caídas de millares de talladores, tejedores, lapidarios, plumarios, preparadores de cueros, yerbateros, herbolarios y muchos otros artesanos, curanderos y prácticos. Espacios privilegiados, bien integrados a los territorios de consumo, fueron quedando en total aislamiento territorial. Aquí se sucedieron situaciones de precariedad y angustia.

La relatividad perceptiva del valor alimenticio de diversos productos autóctonos andinos y de sus zonas periféricas, por los conquistadores hispánicos y sus descendientes mestizos, desencadenó el abandono de asociaciones de cultivos y animales en múltiples sitios geográficos y contribuyó a una cierta desintegración territorial. La utilización masiva de vegetales y animales aborígenes, disminuyó de más de un centenar de especies a poco más de una treintena. En los primeros siglos coloniales se observaba en los paisajes de las haciendas gran disminución de las superficies destinadas al cultivo de la quinua (Chenopodium quinoa), de la caniwa (Chenopodium pallidicaule), de la mashua (Trepoelum tuberosum), de la oca (Oxalis tuberosa) del ulluco (Ullucus tuberosum), de chocho (Lupinus mutabilis) y de otros productos andinos. Estos rubros alimenticios prehispánicos, algunos de ellos virtualmente olvidados como el ataco (Amaranthus quitensis), el sangorache (Amaranthus caudautus), el rizoma de la totora (Scirpus riparius), el llantén (Plantago major) y muchos otros (Naranjo, 1985). En el cruce del desierto de Atacama fue fundamental la recolección de los frutos del algarrobo (Prosopis chilensis), tamarugo (Prosopis strombuifera), chañar (Geoffroca decorticans). Ellos son abandonados en los años de la conquista española, después de haber sido utilizados en las huestes de Pedro Valdivia. Posteriormente, como apoyo alimenticio para las expediciones y viajeros entre Arica y Copiapó se introducen productos livianos neomediterráneos de paisajes próximos, como frutas secas, pasas, harina de trigo, aguardiente, abandonándose por los pobladores hispánicos y sus descendientes gran parte del consumo habitual de los productos autóctonos del desierto. Ello va a acentuar la marginalización geográfica de parte importante de estos paisajes desérticos, sucediéndose la regresión paisajística cultural, salvo en oasis y sitios irrigados.

La relatividad perceptiva del valor de los recursos naturales autóctonos también se evidenció en Chile Central, donde se observó tempranamente la desaparición de auquénidos silvestres y domésticos. Igualmente rápido fue el agotamiento de un sinnúmero de vegetales que eran consumidos por los pueblos originarios, como el illmu, el lahue (Calydorea speciosa), el huanqui (Dioscorea humifosa), el liuto (Alstroemeria ligtu), el magu (Bromus mango), el madi (Madia chilensis), la taca (Elymus agropyroides) y otras especies. Se abandonó tempranamente el consumo del roedor degú (Octodon degus). En el período de la colonización hispánica, por abusos en los procesos de recolección se contraen sustancialmente los paisajes de la palma (Jubaea chilensis), diezmada para elaborar miel, y del pangue (Gunnera chilensis), cuya importancia derivaba de la utilización de su rizoma en las curtidurías, en la farmacopea popular y en la alimentación (Cunill, 1971).

Han sido básicas las contribuciones y rutas de la América Andina a la alimentación mundial, al difundirse el consumo planetario de diversos tipos de maíz, de la papa, del ají andino, del ají manzano, de frijoles, del aguacate, diversos frutales, incluso con la revalorización de la quinua y de la quina, el merkén, el charqui, el chuno, junto a hierbas medicinales ancestrales.

\section{Hacia una mayor comprensión integracionista del neomediterráneo andino}

Uno de los aportes mayores geohistóricos para la comprensión del proceso de integración colonial de América Andina se expresa con la irrupción en sus variados ámbitos territoriales de pobladores del Mediterráneo, junto a sus primicias y transformaciones ecológicas por animales, plantas domésticas, plagas vegetales, enfermedades y modos de vida.

En diversos espacios andinos se fue afianzando el sentimiento del "buen clima", similar o muy parecido al de las comarcas mediterráneas europeas de origen de conquistadores y colonizadores. Ello se posibilitó en los Andes septentrionales con sus extensas tierras altas planas de la altiplanicie de Bogotá y la cundimarquesa-boyacense, al igual que en la sierra central ecuatoriana. Asimismo en la misma zona tropical de los Andes centrales y en las comarcas templadas de los Andes meridionales, en 
las terrazas costeras y Valle Longitudinal de Chile central, junto a parajes irrigados de Mendoza y del noreste argentino.

La visión de los conquistadores mediterráneos estuvo condicionada, en gran parte, por un intento implícito de recuperar o reconstruir la zonalidad perdida de sus paisajes natales. Esta tarea fue sumamente compleja, debido al predominio en la configuración andina de paisajes tropicales de altura. Por ello, el intento de transmutación llevó a los nuevos colonizadores al extremo de trastocar la realidad estacional americana por antiguas imágenes climáticas de sus zonas mediterráneas originarias; así, ha llegado hasta el presente la discutida apelación de "invierno" y "verano" a las temporadas de lluvia y sequía en las zonas tropicales, junto con nominar con ancestrales apelaciones de "tierra templada" o "tierra fría" a nuevas expresiones de ambientes tropicales altos en los Andes.

En su añoranza por los paisajes mediterráneos peninsulares, los conquistadores acarrearon a América Andina importantes conjuntos de la biodiversidad europea, logrando imponerse muchos de ellos a incompatibilidades climáticas y biológicas. Ello se explica en gran parte porque las plantas y los animales introducidos por estos pioneros europeos tenían rasgos dominantes de rusticidad que les permitieron sobrevivir en las pésimas condiciones de traslados que experimentaron en la rigurosa travesía transatlántica y transpacífica, los ascensos andinos y travesías del desierto, por lo que solo los ejemplares más toscos y robustos tendían a adaptarse al ser implantados en América Andina.

Mención especial debe darse a la integración interna con los intentos de aclimatación en América Andina de los productos básicos de la alimentación hispánica de la época: aceite, pan y vino. Sus espacios se convirtieron en campos de experimentación en la búsqueda de suelos y climas propicios para la reproducción de plantas y animales mediterráneos.

El trigo se difundió tempranamente en los oasis del litoral peruano, instalándose allí el primer molino en 1539. Arraigó fácilmente en el Norte Chico y Depresión Central de Chile, para extenderse en terrenos de secano y regadío desde finales del siglo XVI, con sostenidas corrientes de exportación al Perú. Asimismo, tuvo éxito su aclimatación en Cuyo. A su vez, la vid a partir de 1551 arraigó en los oasis del sur del Perú, dando nombre posterior al prestigioso aguardiente de Pisco, afianzándose también de los valles de Nazca, Ica y Arequipa, elaborándose vinos que se exportaban a Guayaquil. En Chile Central el cultivo de la vid prosperó a partir de 1554, extendiéndose por todo el territorio hasta alcanzar su límite ecológico en Angol a finales del siglo XVI, diseñándose comarcas vitivinícolas de significación, como las de Cauquenes y Concepción, por sus vinos tintos de uva mollar. A su vez, vinos y aguardientes cuyanos de la zona de Mendoza tenían un buen mercado, lo mismo que los anteriores en los campamentos mineros, estableciéndose importantes rutas de integración.

En los valles sureños peruanos arraigaron extensos olivares, como en Tacna y Azapa, cuyo fruto se destinaba preferentemente a ser consumido como aceituna. Hacia 1561 se introdujo en Chile el olivo, que ya a fines del mismo siglo se exportaba en forma de aceite a explotaciones mineras del Perú y del Alto Perú, aunque en la cocina criolla chilena se prefirió la grasa de vaca. También tuvo importancia en los paisajes de Mendoza. Hemos expuesto la saga integracionista del vino, aceite y pan, que llegaba a los sitios más alejados de la América Andina profunda.

Las frutas mediterráneas se aclimataron en diversa forma, sirviendo de base a la alimentación minera en forma de frutas secas, como el durazno, el damasco, la manzana, la pera, las pasas, los higos. Es un tema inédito que debería ser desarrollado en extensión.

La carne de la dieta alimenticia del poblador hispanoandino fue provista mayoritariamente por la ganadería de origen europeo, constituyendo una gran aportación a la geografía económica y a los cambios en los modos de vida. Hay que establecer con la debida cartografía temática las rutas del cerdo, del ganado vacuno y caballar, de la oveja y de la cabra. A menudo, los caminos de la integración fueron antecedidos por caballos, acémilas y vacunos asilvestrados.

\section{Mestizaje de sabores, olores y drogas, senderos y caminos de integración}

En la geohistoria de América Andina se experimentan en gran parte de sus espacios de $5.466 .705 \mathrm{~km}^{2}$ y en aproximadamente $286.626 \mathrm{~km}^{2}$ del Noroeste argentino y Cuyo, importantes corrientes de mestizaje cultural, en comarcas unidas por senderos y caminos de integración, de producción, consumo y tráficos comerciales, de productos variados que proporcionaban alimentos, sabores, olores, medicinas, 
drogas. Se marcaban espacios claves para la integración, tales como la quebrada de Humahuaca con su rol de conexión o entrada por sus paisajes para las relaciones entre el resto del Noroeste y el Alto Perú; de los valles Chalchaquíes con sus tráficos de productos agrícolas de viñas, árboles y frutales, cereales, legumbres, y ganadería extensiva; del valle de Lerma que proporcionaba los potreros de invernada de vacunos, mulares y caballares, que se enviaban al Alto Perú y Chile. Una auténtica saga se lograba desde el Nordeste argentino con los tráficos de la yerba mate de los yerbales silvestres de Misiones, con sus redes de picadas que permitieron la salida de este estimulante al ámbito andino.

La mestización de sabores se impone como un mecanismo de integración y subordinación, muy utilizado por los conquistadores españoles. Al mismo tiempo, los pueblos originarios expresaron gran sentido de innovación al agregar a sus asociaciones de cultivos prehispánicos primicias de productos europeos, asimilando con facilidad cultivos como el trigo, la cebada, la avena, los frutales mediterráneos, las hortalizas y la ganadería popular, con el consumo masivo de carne de ovejas, chivos, cerdos, gallinas, y otras especies.

Incluso se constató el vigor de los nuevos productos mestizados en la dieta popular andina, como se evidenció en malestares masivos por la carestía del trigo en la población indígena y mestiza en los Andes, lo que revelaría un distanciamiento de los patrones de consumo autóctono de panes de maíz, y cereales andinos. En un contexto geocultural de la sensibilidad religiosa en el consumo del pan ázimo en hostias, y profana de prestigio social, el pan de trigo mantuvo en América Andina un papel vital en la sensibilidad de su población. Ello se ha explicitado en el caso de Venezuela: “... en el plano cualitativo, se puede comprobar que el trigo tuvo gran importancia, pues mantuvo a lo largo de todo el período estudiado el carácter de alimento superior plenamente identificado con el conquistador militar y religioso" (Lovera, 1999).

En el caso de los panes serían deseables nuevas investigaciones sobre la mestización de los sabores con las rutas de las arepas y los panes de maíz, los panes de la yuca, los plátanos y otros productos panificables. Un capítulo novedoso debería estructurarse con las rutas de los panes de papa y chuño en los Andes Centrales y del chapalele en Chiloé.

Asimismo estimamos que se debería dar mayor atención al establecimiento de cartografías temáticas de las plurales rutas de la sal, porque sales terrestres, vegetales, lacustres y marítimas han suplido las necesidades humanas en América Andina y sus zonas periféricas. En los paisajes andinos dominaba el gusto por la sal terrestre, que se fue contrayendo con su tradicional confección en panelas, salvo en parajes paisajísticos que hemos reconocido en la década de 1980 en sitios recónditos de los Andes equinocciales, en las salinas ecuatorianas del Chota y Bolívar. Fue fundamental el empleo de la sal andina para el beneficio del azogue en la minería de la plata, que se extraía en las minas subterráneas de Yocalla, emplazadas al occidente de Potosí, donde se sacaban más de 60.000 quintales de sal al año con el trabajo de 1180 indígenas (Cunill, 2002). Junto a otras salinas altiplánicas la extracción de sal para la transformación de los minerales alcanzaba a más de 600.000 quintales anuales.

El caso más relevante se expresó en las inmensas salinas marítimas de Araya, que entra, según el historiador Pierre Chaunu, a lo largo de los últimos años del siglo XVI, en el marco de la gran economía mundial. Su puesta en explotación clandestina y más tarde, entre 1593 y 1622, incidió en convertirse en un producto vital para los Países Bajos, provincias de Holanda y Zelanda. Cientos de urcas salineras cruzaban periódicamente el océano Atlántico desde las ciudades de Hoorn, Enkhuizen, Medemblik y otros puertos, hasta las salinas de Araya, conduciendo esta materia prima para procesar quesos, mantequillas, arenques e industria textil tintórea (Cunill, 2011).

A escala menor tampoco se deben desdeñar las corrientes locales de integración salinera del litoral desértico para las salazones de pescados marítimos que eran enviados a los campamentos mineros y comidas de esclavos. Asimismo fue el caso de las salinas de Cahuil, Bucalemu y otras de Chile Central.

Un producto fundamental para la geohistoria de los espacios periféricos hiperhúmedos y cálidos de América Andina y su expresión mundial se expresa en el cacao. En este aspecto es de especial valor para el caso del cacao ecuatoriano la magnífica obra de María Luisa Laviana Cuetos intitulada Guayaquil en el siglo XVIII. Recursos naturales y desarrollo económico. Editado en el 2002 por el Archivo Histórico del Guayas y el Banco Central del Ecuador.

Por nuestra parte estamos concluyendo una investigación intitulada Las rutas del cacao en la 
Venezuela Colonial, patrocinada por la Comisión Nacional de Venezuela de Cooperación con la UNESCO. Se inicia con el planteamiento del controversial origen prehispánico del cacao silvestre en el territorio que hoy corresponde a Venezuela en diferentes zonas geográficas, señalándose rutas aborígenes en su búsqueda en parajes bajos e hiperhúmedos, para luego transportarlo, con auxilio de estimulantes como el hayo, a parajes de tierras altas andinas donde se utilizaba en diversos centros ceremoniales para ofrendas adoratorias. Fue un universo cultural que alcanzaron a conocer conquistadores europeos quienes inclusive encontraron relictos ceremoniales con presencia cacaotera. $\mathrm{La}$ realidad de la existencia de cacahuales silvestres autóctonos se mantuvo virtualmente desconocida en la Orinoquia profunda hasta mediados del siglo XVIII, cuando se produce el hallazgo por expedicionarios hispanovenezolanos de ellos, señalándose varias rutas fluviales y terrestres en su consecución hasta finales de dicho siglo.

Se expone el pormenorizado panorama de la distribución geográfica en diez zonas de las plantaciones cacaoteras coloniales, señalándose las rutas interioranas y de salida del producto hasta diferentes caletas y siete puertos de exportación. Se da especial importancia al sitio de inicio de estas rutas del cacao, caracterizando tipos de hacienda cacaotera y sus sistemas de poblamiento esclavista, con las modalidades del transporte y distribución local. Asimismo se señala la significación de las rutas escondidas del cacao, practicadas por contrabandistas nacionales y foráneos, judíos, sefardíes, holandeses, franceses y otros, añadiéndose las rutas crípticas de los cumbes, con su carácter libertario de población afrodescendiente. Asimismo se expone la significación de las propiedades comunales indígenas en los cultivos cacaoteros, como también la utilización de arboledillas por esclavos para alcanzar su libertad.

La distribución territorial de las diez zonas productivas del cacao de plantación y de persistencias de sitios de recolección de cacao silvestre, con sus rutas internas y externas, ha sido relevante en la geografía histórica del poblamiento venezolano. A diferentes ritmos durante los siglos coloniales se fueron constituyendo con gran esfuerzo en el trabajo y condiciones de vida de indígenas, esclavos afrodescendientes, peones mestizos, criollos y peninsulares, paisajes agrarios destinados al consumo local y a la comercialización exportadora. Ello posibilitó la conformación en varios sitios del país de monocultivos cacaoteros, exportándose al universo euroamericano, particularmente México y España, donde se afianzaron diversas formas de su consumo e importantes ferias, sitios de encuentro para los comerciantes venezolanos.

El cacao fue el más sólido producto de la riqueza venezolana durante el período colonial. Se da especial importancia a las diferentes modalidades de consumo popular del chocolate y del cacao cerrero. El apetito intenso de su consumo, representando además símbolos sociales del lujo y de la concupiscencia incidió en la geografía cultural del poder cacaotero en el país con los grandes cacaos que controlaban las rutas desde sus mansiones urbanas y haciendas de producción rural, donde dominaba el absentismo patronal y la expoliación y despojo de la mano de obra. Estos paisajes cacaoteros coloniales fueron experimentando cambios en sus modos de producción en las últimas décadas del siglo XVIII y sufrieron gran impacto en el período de la Emancipación.

El gusto de los sabores del cacao y del chocolate con la utilización de la vainilla y la canela incidió en expediciones de diverso tipo para su encuentro, como lo hemos analizado en ambos casos en nuestra obra Geohistoria de la sensibilidad en Venezuela. Ello ha llegado incluso a la novelística con el libro del colombiano William Ospina, El país de la Canela. Premio internacional en el 2009 de novela Rómulo Gallegos.

En esta temática interesa desenvolver la vigencia de corrientes de tráficos de drogas y tabacos, con sus antecedentes geohistóricos y conformación de espacios de producción. Investigaciones in situ tendrían notables resultados acerca de las drogas de las selvas, los alucinógenos de los desiertos. El tema mayor se expresaría en el desenvolvimiento de los espacios del hayo y de la coca (Erythroxylum coca), desde producto ritual sagrado de las zonas andinas centrales. Asimismo en los valles templados de Pasto en los Andes septentrionales se cultivaba coca, y los chibchas la recibían en tributo de diversos grupos étnicos emplazados en las tierras calientes de los valles interandinos y piedemonte andino-llanero. Hemos probado su producción en diversos sitios que se diseminaban desde la Guajira hasta Chiribichi. La valorización de la coca como elemento fundamental de la cultura andina se incrementó durante la dominación española, superándose las restricciones a su consumo masivo. Este extraordinario auge del consumo hizo que 
sus cultivos se extendieran a mayores superficies en los valles calientes que comunican las tierras serranas de los Andes equinocciales y centrales con las tierras amazónicas, desde el hinterland quiteño hasta la Ceja de Montaña, Perú, y Yungas, Bolivia, especialmente después de 1545 para servir la demanda en los centros mineros de la plata en Potosí.

Toda barrera se alzó. Los mineros de los pueblos originarios indígenas tenían que emplear la coca para soportar las duras condiciones de trabajo en las labores subterráneas, donde dominaba la muerte. Este consumo era fomentado por las autoridades civiles y eclesiásticas interesadas en los correspondientes diezmos y tributos, como se observa en las ordenanzas de Felipe II sobre el cultivo de coca dictadas en 1573 y en los acuerdos del Segundo Concilio Limense, en la segunda mitad del siglo XVI, como también por los españoles y criollos que controlaban tanto la extracción minera como el comercio y producción de la coca. En cuanto al espacio, ello se revelaba en varias encomiendas coqueras en los yungas durante los siglos XVI y XVII y ulteriormente en múltiples haciendas especializadas en cultivar coca para los centros mineros altiplánicos marcándose espacios de integración funcional vivificados por recuas de llamas y mulares (Cunill, 1999).

A estas corrientes de integración se deberían agregar otro tipo de investigaciones para desenvolver el esclarecimiento de rutas que posibilitaban el placer de peninsulares, mestizos y aborígenes, por el tabaco, que incluso logró desenclavar los espacios de los Andes barinenses por las ríspidas rutas del río Orinoco.

Un tema mayor se debería abordar en el desvelamiento de los tráficos de hierbas y venenos andinos, incidiendo incluso en la distribución del maestresala en los inicios de la conquista, con el pavor a los venenos tradicionales y la vigencia de la obra medicinal de Dioscórides, traducida en 1555 del griego al castellano y anotada por el doctor Andrés de Laguna (Dioscórides, 1991). Hay que rescatar la sabiduría de yerbateros y sanadores ancestrales, en especial las rutas para la sanación por plantas "milagrosas" y las prácticas esotéricas, que aún hoy se mantienen en parajes múltiples de América Andina. Muchas hierbas medicinales andinas fueron incorporadas por el sevillano Nicolás Monardes, quien en 1574 mediante su famosa y difundida Historia medicinal de las cosas que se traen de nuestras Indias Occidentales que sirven en Medicina, se encargó de divulgar sus beneficios y popularizar su consumo, instalando incluso un jardín de aclimatación en la sevillana calle de Sierpes (Monardes, 1988).

Hay que insistir que en el siglo XVIII se extendió en España e Hispanoamérica la utilización de múltiples especies de chinchonas para combatir las fiebres derivadas de la malaria y otros tipos de paludismo, como en siglos anteriores se habían registrado múltiples remedios aborígenes andinos contra los excesos de la gula y de los placeres del cuerpo. Diversas especies de quina lograron gran demanda en los mercados españoles, alcanzándose altos precios, en especial con la proveniente del Perú, desde 1649, que no tuvo competencia hasta 1774 con la difusión de su hallazgo por José Celestino Mutis en Nueva Granada, lográndose entonces un gran ahorro en tiempo y dinero exportando la quina por Cartagena y otros puertos caribeños, en lugar de efectuarlo solo por las costas ecuatorianas y peruanas del océano Pacífico y expendidas por las vías de Panamá y cabo de Hornos.

\section{Las alegrías del vivir en América Andina}

Deseo concluir estas palabras con un llamado a desarrollar en sus futuros estudios nuevas ópticas para abordar las alegrías del vivir en América Andina. Aquí se palpita en todos sus paisajes la trascendencia de la alegría, aun en los territorios costeños, puneños y piedemontanos, donde habitan sectores sumamente desposeídos. Sus expresiones de regocijo transcurren en sus chozas, ranchos y diversos tipos de viviendas humildes, habilitadas en creativos usos de recursos de la flora local y/o materiales de desecho con un bricolaje artesanal, con actividades manuales con la ayuda, intercambios y reciprocidades de los miembros de sus respectivas comunidades.

Pesares, hambrunas, vejaciones en la pobreza, en los entornos de sus destartaladas viviendas, se alejan en momentos estelares para pobladores autóctonos, mestizos, blancos, afrodescendientes, en chicherías, picanterías, ferias. Toda esa pobreza está movida por una energía y una belleza sin igual. Este universo andino lo inmortalizó José María Arguedas en 1958 en su novela Los ríos profundos, al proporcionar su visión del ámbito andino quechua y mestizo.

La alegría del vivir se marca también en los espacios de distensión y ocio, con la pasión en América Andina por la fiesta y el espectáculo en los espacios públicos de calles y plazas. Toros, gallos y diversos juegos se desenvuelven en una larga 
tradición geohistórica. El regocijo popular se ha marcado en siglos en las máscaras, las mojigangas, las tramoyas, las luminarias, las competencias del volantín y de los cometas, y los combates festivos de apedreamientos.

Resulta cautivante estudiar que incluso en los ríspidos y desolados paisajes del altiplano se conformaron gratos paisajes de la distensión, como se observó en la ciudad de Potosí con la irrupción de salones de fiestas, esgrima, cursos de baile, billares y juegos, que sedujeron a los potosinos, tanto a los sectores sociales más opulentos como al pueblo en general. Han quedado cuadros que revelan la fuerza de estos actos, en las fastuosas entradas de las comitivas gubernamentales y obispales, como el del pintor Pérez de Holguín sobre la Entrada del Arzobispo Diego Morcillo Rubio en Potosí, 1713, hoy en el Museo de América en Madrid. En todas las ciudades andinas durante el Corpus Christi los gremios rivalizaban para demostrar quién se montaba los altares más hermosos, vestían mejores galas en la procesión o sacaban las carrozas más costosas.

La alegría religiosa en las grandes festividades y movimientos de peregrinaje se continúan visualizando en América Andina, en sus tumultuosas procesiones, en especial en Semana Santa. Mención especial merece el establecimiento de una cartografía temática de las fastuosas procesiones en las fiestas patronales, partiendo de sitios claves como las de la Virgen de Cocharcas en Andahuaylas, de Santa Rosa de Chiquián en Ancash y las de magnitud excepcional al santuario de la Virgen de Copacabana a orillas de Titicaca.

Aún se registra la vigencia de algunas fiestas consideradas entre las más importantes del ámbito rural andino. Es el caso de la fiesta Yarqa Aspiy o fiesta del agua. Aquí se renuevan los mitos, creencias y rituales asociados a la religiosidad prehispánica sobre el uso del agua y de la champería. Destacan asimismo en ámbitos andinos periféricos la persistencia de fiestas, danzas y peregrinaciones rituales de profunda raigambre indígena que se enmascaran con la celebración del santoral y festividades emblemáticas católicas. En efecto, la sensibilidad aborigen al culto a la deidad Ches, un espíritu supremo dispensador del bien y del castigo, se sigue practicando en algunos páramos andinos septentrionales, como el de Acequias, recordando la Bajada del Che, de los tiempos prehispánicos. Más común fue el aprovechamiento de algunos rasgos efímeros que vivificaban el paisaje en días sagrados como la reconversión de las festividades de la Virgen de las Mercedes, de la danza de las Turas, practicadas por los indígenas ayamanes en varios sitios áridos de los actuales estados venezolanos de Falcón y Lara. Gran parte del sincretismo expresado en la imbricación en importantes días del santoral católico con fiestas, baños y danzas rituales paganas se manifiesta en los ciclos festivos a los solsticios de invierno y de verano en el hemisferio boreal.

Otra fiesta bien celebrada era el Carnaval: disfraces, comparsas, comidas populares, músicos, bailes, fuegos artificiales. Desde las costas donde fueron extendiéndose celebraciones de afrodescendientes se extendió a las tierras altas con modalidades que se mantienen hasta la actualidad.

Debemos dar importancia en las alegrías del vivir en América Andina al tratamiento geohistórico de la música y las danzas, lo que se ha efectuado en otras latitudes ${ }^{2}$. Se ha logrado recopilar información sobre las mismas en los Andes peruanos, ligadas a un conjunto de prácticas culturales que evidencian la estrecha relación de estas con los diferentes momentos claves del ciclo vital de bautizos, matrimonios, funerales, como también al ritmo del calendario agroganadero y las fiestas ceremoniales y rituales religiosos: "Se tiene por ejemplo un cuadro de las danzas en Sucre, Cangallo y Vilcashuaman, en Ayacucho, entre las que figuran las de los Negritos, de las Tijeras, Huaylía, Wayno, Qachua, de Carnaval, del Toril, del Capitán, Inca colla..." (INCP, 2004). En música hay informaciones de registro de instrumentos musicales, algunos cuya práctica se está perdiendo, como el longhor huancavelicano, el mamaq ayacuchano y la roncadora ancashina (INCP, 2004). Se experimentó un gran impacto peninsular ante estos instrumentos musicales y cánticos.

Asimismo en los sones de América Andina se ha registrado la hipersensibilidad ante los cánticos religiosos, habiendo tenido gran importancia los sonidos musicales en el sometimiento indígena misional. Hace apenas 30 años con la recuperación arquitectónica de las magníficas iglesias de las llanuras amazónicas de Moxos y de la Chiquitania cruceña, se fue teniendo constancia de la existencia de un gran patrimonio musical barroco, de miles de partituras y hojas de música sacra, misas cantadas, óperas y villancicos, compuestas por europeos e indígenas, que empezaron a aparecer en sacristías casi derruidas, en casas particulares y en comunidades 
apartadas en las que padres a hijos se habían custodiado en secreto. Esta labor se está recogiendo en San Ignacio de Moxos en el Archivo Misional en Concepción (Montalbán, 2009).

En los estudios de integración geohistórica de América Andina hay que seguir la persistencia de la música aborigen y mestiza en espacios rurales y urbanos. José María Arguedas en su citada novela plantea que hay melodías ancestrales que nos permiten recuperar imágenes paisajísticas visuales: "Acompañando en voz baja la melodía de las canciones, me acordaba de los campos, y de las piedras, de las plazas y de los templos, de los pequeños ríos donde fui feliz" (Arguedas, 2007). Por ejemplo, los cantos de la trilla de las alverjas en la villa de Pampas, capital de la provincia de Tayacaja, o los cantos de la trilla triguera en Chile Central.

Las composiciones populares del tipo tradicional se siguen usando corrientemente. Son las canciones espontáneas del pueblo, como en la sierra peruana los jarahuis y los huaynos. Los jarahuis eran estimados en el Imperio Incásico como la forma más excelsa de la poesía y de la música. Son cantos de imprecación entonados por mujeres, siempre en coro, durante las despedidas o la recepción de las personas muy amadas o muy importantes, durante las siembras y las cosechas. La integración paisajística se marca en los huaynos, canciones de distintas regiones del país, tanto antiguas como modernas. Su primacía se expresa en que es la composición más popularizada en Perú. Más aún, tiene la condición de fraguador de la nacionalidad peruana, es una música que integra entre sí a todos los peruanos y al mismo tiempo los religa con sus orígenes prehispánicos: "como hace cuatro siglos el wayno es la fuerza, es la voz, es la sangre eterna de todas las fiestas del Perú del Ande" (Rama, 2007). Obviamente es la transculturación del mestizaje. Es el caso de la cueca en Chile, ícono de las fiestas patrias.

Me tomo la licencia de hacer un llamado a la reflexión de este público joven que indudablemente cumplirá un importante rol en la educación del futuro, en tiempos difíciles, en que se cuestionan desconsiderados disfrutes individuales y sociales, marcados por un consumo incesante y lucro desmedido, sin ningún cuidado ambiental. A este respecto insinúo a que sigan con atención los caminos integracionistas del buen vivir, algunos de los cuales ya están esbozados en las recientes constituciones de dos naciones andinas, que acogen los conceptos del buen vivir de pueblos originarios, del Sumak Kawsay y del Suma Qamaña.

Catedráticos como José María Tortosa de la Universidad de Alicante están divulgando los alcances de estos hitos constitucionales andinos del Ecuador y Bolivia inspirados en la herencia de sus pueblos originarios: "En efecto, en la Constitución ecuatoriana de 2008 puede leerse que se reconoce el derecho de la población a vivir en un ambiente sano y ecológicamente equilibrado, que garantice la sostenibilidad y el buen vivir, sumak kawsay. Por su parte, la Constitución boliviana de 2009 es algo más que prolija al respecto, pues recoge la pluralidad lingüística del país que dicha constitución reconoce como plurinacional, y dice que el estado asume y promueve como principios ético-morales de la sociedad plural: ama qhilla, ama llulla, ama suwa (no seas flojo, no seas mentiroso ni seas ladrón), suma qamaña (vivir bien) ñandereko (vida armoniosa), teko kavi (vida buena), ivi maraci (tierra sin mal) y qhapaq ñan (camino o vida noble). Un derecho en un caso y un principio ético-moral en el otro, pero ambos referidos a ese Buen Vivir o, mejor, a ese Buen Convivir del que algo se ha escrito y publicado presentándolo en muchos casos como alternativa al pensamiento sobre el desarrollo y, en más de uno, como hallazgo fundamental en la presente coyuntura del sistema mundial" (Tortosa, 2009) ${ }^{3}$.

Desde la óptica geohistórica llama la atención de que estos conceptos del buen vivir y del adecuado convivir en abarcadora armonía interna y respeto a la naturaleza, provienen del vocabulario de pueblos originarios quechua y aymara, cuyos aportes fueron silenciados y encubiertos desde los centenarios procesos de conquista, colonización e independencia. Ahora comienza a ser superada esta injusta marginalización al aportarse metas diferentes para alcanzar la felicidad en este ámbito andino.

\section{Colofón}

Al culminar esta disertación me retiro con especial complacencia al haber expuesto sucintamente algunos de los mayores desafíos geohistóricos que se han conformado para una debida realización de la integración interna de los variados paisajes de América Andina, que cubren territorios de magnitud planetaria. Desde esta entrañable Arica, punto de inflexión y lugar de encuentro de civilizaciones milenarias originarias, enriquecidas con mestizajes provenientes de diversas realidades étnicas de varios continentes, 
tenemos la obligación de trabajar en nuestro devenir profesional en hacer realidad la afirmación de una auténtica integración de América Andina cumpliendo el reto de unidad en la pluralidad.

Considero que hay que valorar las potencialidades territoriales, ambientales y humanas de América Andina, ante el desencadenamiento de la crisis prospectiva de la artificialización geográfica de los países industrializados, particularmente en Norteamérica, Europa y Extremo Oriente. No tenemos dudas que nuestro rico legado geohistórico con su venero de recursos naturales abre una perspectiva renovada ante su gran potencial espacial de biodiversidad, de recursos energéticos, mineros, pesqueros, agropecuarios, forestales, paisajísticos y otros en el temprano siglo XXI.

La situación geoestratégica de la integración de las naciones andinas con su apertura al océano
Pacífico y al mar Caribe cobrará una amplia dimensión en las próximas décadas, al considerar que se acentuarán aún más a corto plazo tiempos difíciles y críticos, tanto en Europa como en Asia, que paradojalmente son inestables en su prosperidad financiera, al no contar con adecuada base propia de recursos territoriales, con escaso patrimonio ambiental cada vez más dañado por el cambio climático y la intensificación de la geografía de los desastres, y exiguas materias primas naturales, acompañadas con deterioro progresivo en su exangüe ambiente y escasa superficie geográfica.

En cambio, para nuestra América Andina es la hora de realizar esperanzas, con cambios en sus estilos de desarrollo, alcanzando realizaciones audaces en el marco de un desenvolvimiento del bienestar social sustentable y sostenido.

¡Muchas gracias!

\section{Referencias Citadas}

Allende, Andrés R.

1971 La frontera y la Campaña del estado de Buenos Aires (1852-1853). Universidad Nacional de la Plata. 1958, pág. 8. Álvarez Cienfuegos, Juan

2005 La frontera como hábitat. Ensayo en la obra coordinada por Leopoldo Zea y compilada por Hernán Taboada, Latinoamérica en la globalización y el tercer milenio. Tomo III, La frontera como reto. Instituto Panamericano de Geografía e Historia. Fondo de Cultura Económica, 2005, pp. 15 y 16.

Anazarbeo, Pedacio Dioscórides

1991 Acerca de la materia medicinal y de los venenos mortíferos. Traducido del griego e ilustrado por el doctor Andrés de Laguna. Anvers. Casa de Juan Latio, MDLV, Edición facsimilar de la Consejería de Agricultura y Cooperación de la Comunidad de Madrid.

Arguedas, José María

2007 Los ríos profundos. Fundación Editorial el perro y la rana. Caracas, 2007, p. 93.

Arze Aguirre, René

1999 Bolivia en el Siglo XX. La formación de la Bolivia Contemporánea. Publicación bajo la dirección de Fernando Campero Prudencio. La Paz. 1999, René Arze Aguirre, Notas para una Historia del Siglo XX en Bolivia, p. 49.

Bate, Luis Felipe

1983 Comunidades primitivas de cazadores recolectores en Sudamérica, en Historia general de América, dirigida por Guillermo Morón, vol. 2, Italgráfica, Caracas, p. 190.

Blache, Jules

1942 L'homme et la montagne. Gallimard, Paris, 1942, págs. 166 a 170.

Casanueva, Fernando

1998 Indios malos en tierras buenas. Visión y concepción del mapuche según las élites chilenas del siglo XIX. Investigación en la obra Modernización, inmigración y mundo indígena. Chile y La Araucanía en el siglo XIX.
Editor Jorge Pinto Rodríguez. Ediciones Universidad de La Frontera.Temuco,1998, pág. 130.

Contreras, Carlos; Marcos Cueto

2007 Historia del Perú contemporáneo. Instituto de Estudios Peruanos, Lima, 2007, pp. 216 a 218.

Cunill Grau, Pedro

1971 Factores en la destrucción del paisaje chileno: recolección, caza y tala coloniales, en Informaciones Geográficas, Instituto de Geografía, Universidad de Chile, 1971, No XX, pp. 235-264.

Cunill Grau, Pedro

1972 Fuentes cartográficas en la génesis de los tipos de poblamiento chileno. Siglos XVI al XVIII. Departamento de Geografía, Universidad de Chile, 1972. Apartado del Primer Symposium Cartográfico Nacional, págs. 141-144. Cunill Grau, Pedro

1998 El Orinoco en la historia de Guayana. Investigación en la obra colectiva Orinoco. Uyapari. Biblioteca Nacional. Caracas. 1998, p. 9.

Cunill Grau, Pedro

1999 La Geohistoria. Contribución en la obra Para una historia de América. 1. Las estructuras. Coordinada por Marcello Carmagnani, Alicia Hernández, Ruggiero Romano. Colegio de México. Fideicomiso Historia de las Américas. Fondo de Cultura Económica. México. 1999. Pp. 72 y 73. Cunill Grau, Pedro

2002 Potosí: ciudad minera y valorización ambiental altiplánica. En revista Urbana, Instituto de Urbanismo, Universidad Central de Venezuela, $\mathrm{N}^{\circ} 31$. Caracas, julio-diciembre 2002, p. 95.

Cunill Grau, Pedro

2011 Geohistoria de la sensibilidad en Venezuela. Fundación Empresas Polar. Caracas, 2011, p. 379.

Dion, Roger

1947 Les frontiéres de la France, Hachette, Paris, pp. 15 a 23. 
Emperaire, Joseph

2002 Los nómades del mar. Traducción del Luis Oyarzún. Santiago de Chile, LOM Ediciones, 2002, pp. 306 a 322.

Greve, Ernesto

1938 Historia de la Ingeniería en Chile. Santiago, 1938

Tomo I, pp. 534 y ss.

Instituto Nacional de Cultura del Perú

2004 Proyecto Qhapaq Ñan. Informe de Campaña 2002-2003.

Lima, 2004.

Le Paige, Gustavo

1957 Antiguas culturas atacameñas en la cordillera andina, en Anales de la Universidad Católita de Valparaíso, 1957$1958, \mathrm{~N}^{\circ} 4$ y 5, p. 32.

Lovera, José Rafael

1999 Alimentación e historia en la Venezuela colonial: el caso de los panes, en la obra colectiva Para una historia de América. Los nudos, Fondo de Cultura Económica, México, 1999, p. 74.

Mari, Oscar Ernesto

2003 Un paradójico fenómeno en el Chaco argentino de los años 30. Apogeo económico y delito organizado. Artículo en la Revista de Historia de América. IPGH. Número 132, enero-junio 2003. México, p. 102.

Monardes, Nicolás

1988 Historia medicinal de las cosas que se traen de nuestras Indias Occidentales que sirven en Medicina. Sevilla 1574. Edición facsimilar Padilla Libros, Sevilla, 1988.

Montalbán Carrasco, Juan Francisco

2009 Bolivia y el rastro esquivo de lo perdido. En Nombres propios, 2009, Fundación Carolina, Madrid, p. 114.
Naranjo, Plutarco

1985 Desnutrición: problemas y soluciones. Editorial Olmedo, Quito, p. 33.

Parés, Carmen Elena

1995 Huellas Ka-Tu-Gua. Ensayos. Caracas, Consejo de Desarrollo Científico y Humanístico. Universidad Central de Venezuela. 1995. Primer Volumen, pp. 21 y 22.

Rama, Ángel

2007 Prólogo, a Los ríos profundos, intitulado La novelaópera de los pobres, op. cit., pp. 23 a 25.

Saavedra, Alejandro

1971 La cuestión mapuche. Instituto de capacitación e investigación en Reforma Agraria. Santiago de Chile.

Sanoja, Mario

1992 De la recolección a la agricultura, Volumen 3 de la Historia General de América, bajo la dirección de Guillermo Morón, 1992, p. 9.

Tortosa, José María

2009 Sumak Kawsay, Suma Qamaña, Buen vivir. En Nombres propios, Fundación Carolina, Madrid, pp. 132-133.

Vicens Vives, Jaime

1958 Tratado general de geopolítica. Universidad de Barcelona, p. 165.

Villalobos, Sergio

1995 Vida fronteriza en La Araucanía. El mito de la guerra de Arauco. Editorial Andrés Bello. Santiago de Chile, 1995, pág. 202.

\section{Notas}

1 Ver hermosos grabados en la obra del presbítero Manuel María Albis Curiosidades de la montaña i médico en casa, 1854. Reproducido por Giorgio Antei, Guía de Forasteros. Viajes ilustrados por Colombia. 1817-1857. Seguros Bolívar. Bogotá, 1995, pp. 120 a 129.

2 Ver Roberto Lobato Correa y Zeny Rosendahl, Literatura, música e espaco. ED. UERJ. Río de Janeiro. 2007. Los aportes de G.O. Carney, The geographic of music: inventory and prospect-1990. Music and place, 2003 (country blues to hop).

3 Es ilustrativa sobre esta temática la obra de Alberto Acosta, Edgardo Lander, Eduardo Gudynas y otros, El buen vivir. Una vía para el desarrollo, Quito, Abya-Yala, 2009. 

ANDROS IMPRESORES

www.androsimpresores.cl 